\title{
Study on Pravargya: A Vedic Process to Destroy Viruses and Boost Immunity by Producing Rapid Sun Surface Temperatures
}

\author{
Dr. Venkata Chaganti*, Murali Cheruvu*** \\ * President, Vedas World Inc., Atlanta, USA \\ ** Data Analyst, Vedas World Inc., Atlanta, USA \\ DOI: 10.29322/IJSRP.11.02.2021.p11038 \\ http://dx.doi.org/10.29322/IJSRP.11.02.2021.p11038
}

\begin{abstract}
Pravargya is a vedic scientific process in Soma Yaga. We have studied the results of the Pravargya during a Soma Yaga conducted in Hyderabad from $14^{\text {th }}$ to $25^{\text {th }}$ of December 2020. During the Pravargya Process, it was observed that Sun Surface temperatures (> 5000K) were produced for a short time (in seconds) along with possible Ultraviolet A (UVA). Our research shows how Pravargya potentially can destroy the viruses like COVID-19 and harmful bacteria and improve immunity in the living beings through excitation of organic compounds from Cow Ghee, Cow Milk, and Goat Milk by offering them in the yaga.
\end{abstract}

Index Terms- COVID-19 Herbal Medicine, Medical Smoke, Pravargya, Soma Yaga, Yajna

\section{INTRODUCTION}

$\mathrm{T}$ he process of Yajna involves fire that releases heat, and light along with gaseous products. In the Yajna process the most

important ingredients are wood sticks, ghee, herbs, grains, and food prepared from grains, jaggery, saffron, and dry fruit nuts etc. All these materials are organic compounds that are vaporized at low temperatures between $200^{\circ} \mathrm{C}$ to $600^{\circ} \mathrm{C}$. Wood cellulose [1] decomposes at $350^{\circ} \mathrm{C}$ and most sugars at $160^{\circ} \mathrm{C}$ to $180^{\circ} \mathrm{C}$. The products of combustion are generally organic compounds [2] along with $\mathrm{CO}_{2}, \mathrm{H}_{2} \mathrm{O}$ and others. Some of these organic compounds like camphor that are volatile may ignite and burn causing flame that produce colors. During the flaming phase the fuel undergoes a chemical change along with release of heat and other gases. Benjamin et al [3] used muffle and flame burning to combust herbaceous biomass and found that high concentrations of $\mathrm{P}$ (Phosphorous) remained in the ash and most Carbon $(\mathrm{C})$ and Nitrogen $(\mathrm{N})$ being volatized (> 99\%). Mike et al [4] measured temperature profiles of bushfire flames and noted that the maximum temperature $\left(1100^{\circ} \mathrm{C}\right)$ was near the base of the flame.

\section{IDENTIFY AND RESEARCH}

Soma Yaga [5] is a type of Yajna that is done for about several days continuously between Sunrise and Sunset for about 8 hours or more. During this Yaga, a special process called as "Pravargya" [6] is conducted in which cow ghee, cow milk, and goat milk are utilized. Recently Vajepeya Soma Yaga was conducted on the outskirts of Hyderabad, Telangana, India from $14^{\text {th }}$ to $25^{\text {th }}$ December 2020. During this Yajna/Yaga the Pravargya process was done several times. During the Pravargya process a special clay pot (called Mahavira) is prepared with mud collected from special places in the area near the Yajna Shala (a place where the Yaga is conducted). This pot is first heated for a good amount of time and then cow ghee is poured in the pot to fill it. Then the heating is continued till the cow ghee has arrived till boiling point. At this juncture cow milk and goat milk are freshly milked and taken in a long spoon. This mixture of milks is offered carefully on the boiling (about $250^{\circ} \mathrm{C}$ ) ghee pot (Mahavira) and spontaneously a big fire ball is produced that rises to a height about $12 \mathrm{ft}$ or so. 
When cow milk and goat milk combination is offered on top of the boiling ghee pot, the water part (about $87 \%$ ) vaporizes instantly due to high heat quantity. The change from liquid to vapor expands water to several hundred times and pushes the fire above it upwards that produces the fireball.

The main ingredient that is used in Yajna apart from wood is cow ghee that contains many organic compounds. Table-1 gives the details of the ingredients of pure cow ghee [7] for each $100 \mathrm{ml}$. Table-2 gives the ingredients of grass-fed cow milk that contains majorly organic compounds [8]. The table gives the ingredients that are present for each $100 \mathrm{ml}$ of grass-fed milk. Table-3 gives the ingredients of whole goat milk that contains majorly organic compounds [9]. The table gives the ingredients that are present for each $100 \mathrm{ml}$ of whole goat milk. From the tables it is evident that majority ingredients in the cow ghee, cow milk, and goat milk are found to be organic compounds and other elements are found to be in $\mathrm{mg}$.

\begin{tabular}{lll} 
Name & \multicolumn{1}{c}{ Amount } & Unit \\
\hline Energy & 767 & $\mathrm{kcal}$ \\
\hline Protein & 26.67 & $\mathrm{~g}$ \\
\hline Total lipid (fat) & 73.33 & $\mathrm{~g}$ \\
\hline Carbohydrate, by difference & 0 & $\mathrm{~g}$ \\
\hline Fiber, total dietary & 0 & $\mathrm{~g}$ \\
\hline Sugars, total including NLEA & 0 & $\mathrm{~g}$ \\
\hline Calcium, Ca & 1733 & $\mathrm{mg}$ \\
\hline Iron, Fe & 53.33 & $\mathrm{mg}$ \\
\hline Potassium, K & 1567 & $\mathrm{mg}$ \\
\hline Sodium, Na & 0 & $\mathrm{mg}$ \\
\hline Fatty acids, total saturated & 46.67 & $\mathrm{~g}$ \\
\hline Fatty acids, total trans & 0 & $\mathrm{~g}$ \\
\hline Cholesterol & 200 & $\mathrm{mg}$ \\
\hline
\end{tabular}

Table - 1 Cow Ghee (courtesy USDA) per $100 \mathrm{ml}$

\begin{tabular}{lll} 
Name & Amount & Unit \\
\hline Energy & 54 & $\mathrm{kcal}$ \\
\hline Protein & 3.75 & $\mathrm{~g}$ \\
\hline Total lipid (fat) & 2.08 & $\mathrm{~g}$ \\
\hline Carbohydrate, by difference & 5 & $\mathrm{~g}$ \\
\hline Fiber, total dietary & 0 & $\mathrm{~g}$ \\
\hline Sugars, total including NLEA & 5 & $\mathrm{~g}$ \\
\hline Calcium, Ca & 125 & $\mathrm{mg}$ \\
\hline Iron, Fe & 0 & $\mathrm{mg}$ \\
\hline Sodium, Na & 54 & $\mathrm{mg}$ \\
\hline Vitamin C, total ascorbic acid & 0 & $\mathrm{mg}$ \\
\hline Vitamin A, IU & 125 & $\mathrm{IU}$ \\
\hline Fatty acids, total saturated & 1.25 & $\mathrm{~g}$ \\
\hline Cholesterol & 6 & $\mathrm{mg}$ \\
\hline
\end{tabular}

Table - 2 Grass Fed Cow Milk (Courtesy USDA) $100 \mathrm{ml}$ 


\begin{tabular}{lll} 
Name & Amount & Unit \\
\hline Energy & 67 & $\mathrm{kcal}$ \\
\hline Protein & 3.33 & $\mathrm{~g}$ \\
\hline Total lipid (fat) & 3.75 & $\mathrm{~g}$ \\
\hline Carbohydrate, by difference & 4.17 & $\mathrm{~g}$ \\
\hline Sugars, total including NLEA & 4.17 & $\mathrm{~g}$ \\
\hline Calcium, Ca & 108 & $\mathrm{mg}$ \\
\hline Potassium, K & 196 & $\mathrm{mg}$ \\
\hline Sodium, Na & 33 & $\mathrm{mg}$ \\
\hline Fatty acids, total saturated & 2.5 & $\mathrm{~g}$ \\
\hline Cholesterol & 8 & $\mathrm{mg}$ \\
\hline
\end{tabular}

Table-3 Whole Goat Milk (Courtesy USDA) $100 \mathrm{ml}$

This research work is the outcome of the beneficial results of the Pravargya process that took place during Vajepeya Soma Yaga.

\section{DATA, RESULTS AND ANALYSIS}

\section{A. Data Collection}

During the Vajepeya Soma Yaga, Pravargya was conducted five times in a day. We have collected five videos of these conductions and divided each video into chronological time intervals and placed the screenshots of each video in Tables 4 to Table 8. First column of each table gives the complete fireball which is produced during the process. Second column gives the fireball picture in the chronological division of that process. Third column gives the maximum temperature in the fireball during that interval. The temperature of the fireball is calculated based on the RGB values during that interval using a python program. These temperatures are obtained using a python program by calculating color temperature from CIE 1931xy coordinates of the images taken chronologically from the video of the fireball. Figure -1 gives the Color Temperature chart for comparison with the fireball colors and temperatures that were produced during Pravargya.

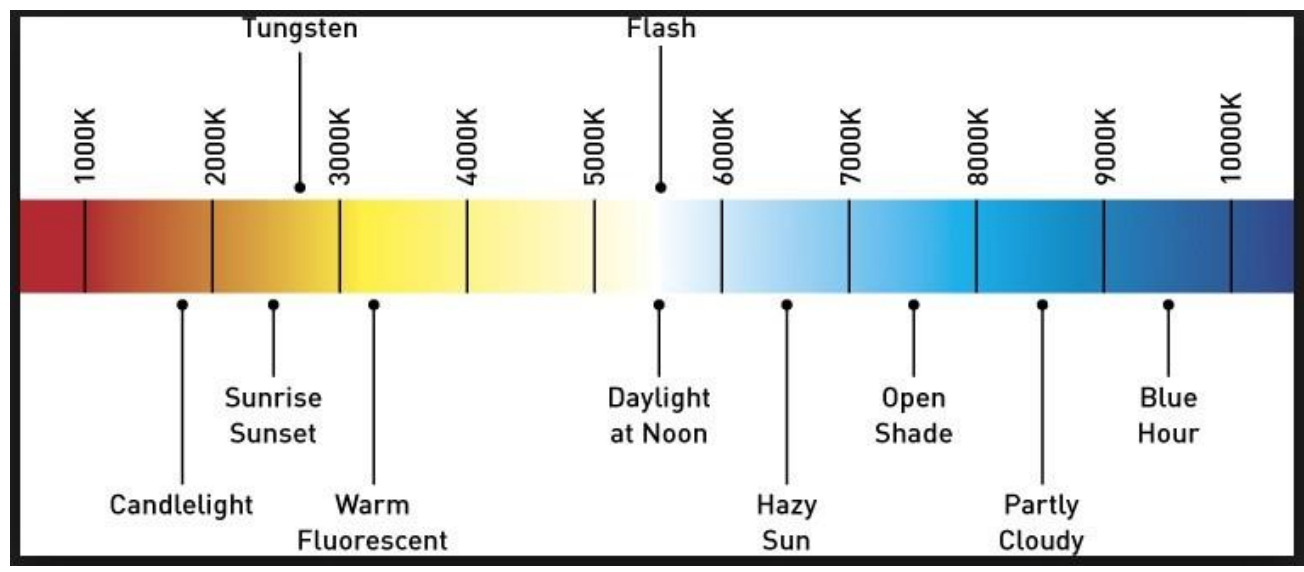


Figure 1: Kelvin (K) Color Temperature Chart. Sun Surface Temperature is around 5,778K. Image Courtesy - https://studioworkscinematic.com/kelvin-and-color-temperature/

\begin{tabular}{|l|l|l|}
\hline Pravargya Sample 1 & $\begin{array}{l}\text { Image } \\
\text { (Chronological } \\
\text { Order) }\end{array}$ & $\begin{array}{l}\text { Max. } \\
\text { Temp } \\
\text { Kelvin }\end{array}$ \\
\hline & & \\
\hline \\
\hline
\end{tabular}

Table-4 Minimum and Maximum Temperatures produced in Pravargya Process - 1

\begin{tabular}{|l|l|l|}
\hline Pravargya Sample 2 & $\begin{array}{l}\text { Image } \\
\text { (Chronological } \\
\text { Order) }\end{array}$ & $\begin{array}{l}\text { Max. } \\
\text { Temp } \\
\text { Kelvin }\end{array}$ \\
\hline & & \\
4209 \\
\cline { 2 - 4 } \\
\hline
\end{tabular}

Table-5 Minimum and Maximum Temperatures produced in Pravargya Process - 2 


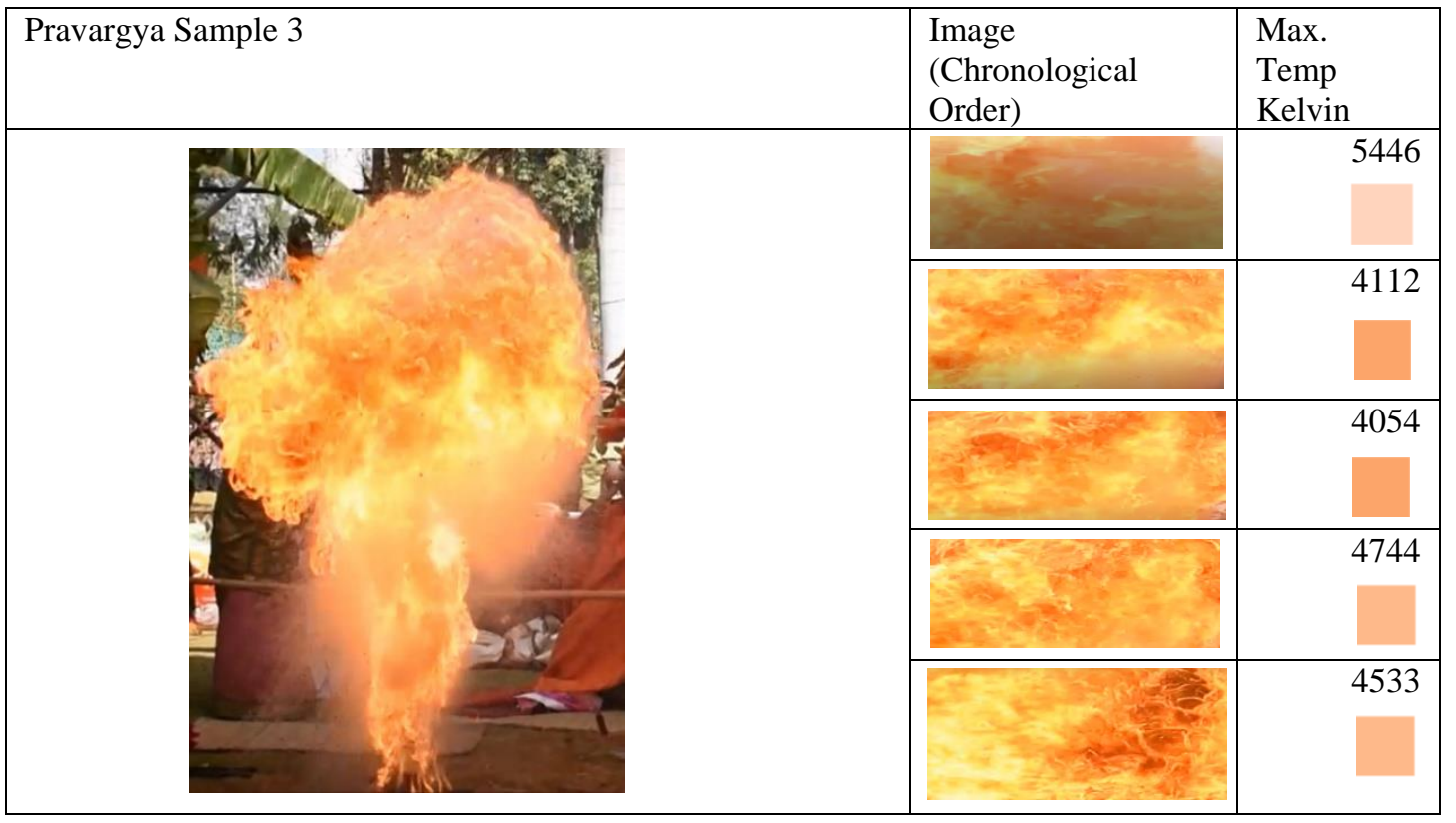

Table-6 Minimum and Maximum Temperatures produced in Pravargya Process - 3

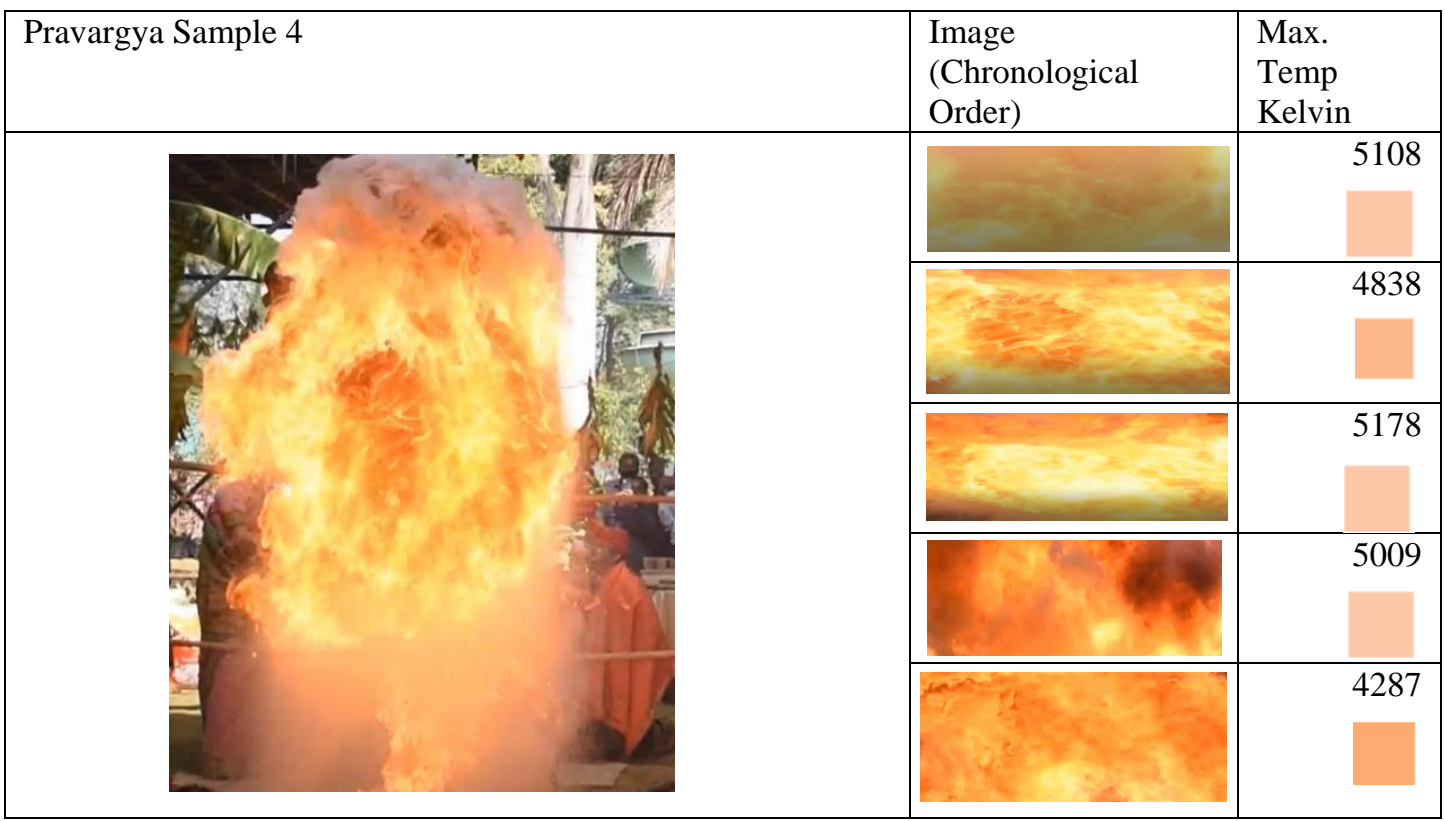

Table-7 Minimum and Maximum Temperatures produced in Pravargya Process -4 


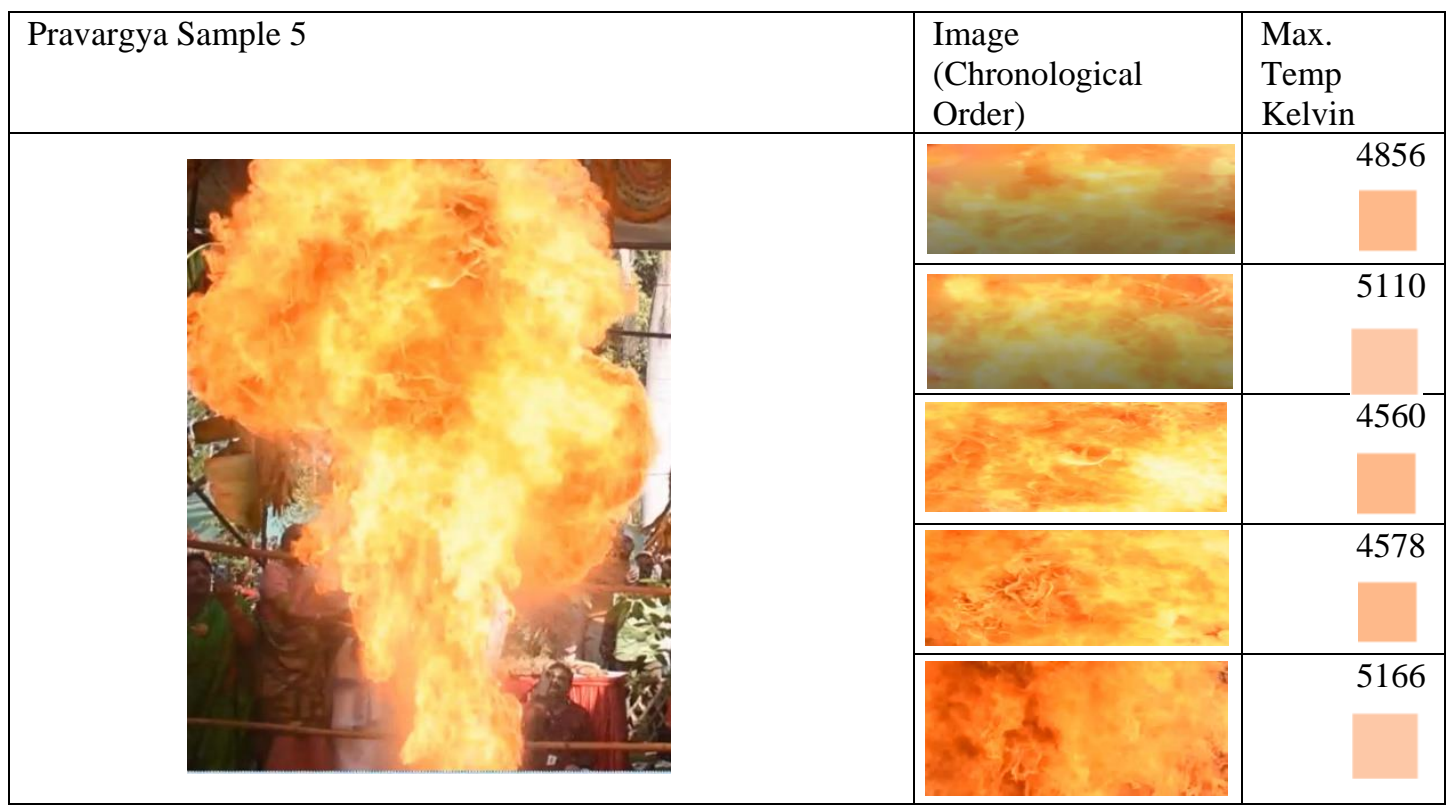

Table-8 Minimum and Maximum Temperatures produced in Pravargya Process - 5

\section{A. Results and Analysis}

Dimitrova et al [10] experimentally found that fat content in the cow milk influenced the scattering and fluorescence spectra in between $200 \mathrm{~nm}$ and $1100 \mathrm{~nm}$ when excited absorption spectra peaked at about $328 \mathrm{~nm}$ and scattering spectra peaked at about $500 \mathrm{~nm}$. This indicates that the fire ball produced during the Pravargya process will show similar results due to the cow milk absorption and scattering peak at about $328 \mathrm{~nm}$ and $500 \mathrm{~nm}$. Vanya et al [11] set excitation spectra at $255 \mathrm{~nm}$ for a mixture of goat and cow milk and found emission wavelengths to be around $350 \mathrm{~nm}$. There is no absorption or emission spectra between $328 \mathrm{~nm}$ and $500 \mathrm{~nm}$. This indicates the fire ball produced in the Pravargya process must have an emission wavelength of $350 \mathrm{~nm}$ due to the fire ball. Ultraviolet A (UVA) is in the range of $320 \mathrm{~nm}$ to $400 \mathrm{~nm}$ and is many researchers have shown that these UVA rays are useful for treating skin problems in humans. In their research work Krutmann et al [12] found that UVA and UVB phototherapy involves immunomodulatory consequences apart from antiproliferative effects. Edward et al [13] research indicates that UVB initiates Melanoma and UVA does not. Anuradha et al [14] concluded that the popular skin therapy is by using sesame oil that contains psoralen and UV ray exposure.

Tables 4 to 8 give details of the temperatures produced in the fireball in chronological order in the five attempts done to produce the fireball. The highest temperature that is produced in the fireball is found to be $5446 \mathrm{~K}$ from Table- 6 and it is equal to the surface temperature of Sun. Even though the time period of such high temperatures is small, the beneficial effects are many. By using the Wein's displacement law for blackbody radiation, we can find the corresponding light wavelengths for these temperatures. For the temperature $5446 \mathrm{~K}$ the corresponding wavelength would be $532 \mathrm{~nm}$ which should be expected as given by the research works [11]. 
Since goat and cow milk were used along with cow ghee, and a wavelength of $532 \mathrm{~nm}$ is obtained, there must have been radiation emitted in the UVA region that could not be obtained in the images taken.

Naveed et al [15] worked on heated ghee and non-heated ghee Fluorescence emission spectra using excitation wavelengths 280 nm, and $410 \mathrm{~nm}$. It was observed that the non-heated ghee peaked at $375 \mathrm{~nm}, 390 \mathrm{~nm}, 440-460 \mathrm{~nm}, 490 \mathrm{~nm}, 620-700 \mathrm{~nm}$ and for heated ghee the Fluorescence peaked at 552nm. In Pravargya ghee is heated to a very high temperature before the combination of cow and goat milk is offered. From our calculations we show that $5446 \mathrm{~K}$ temperature was produced that aligns with the research works mentioned above. Therefore, the possibility of UVA (320 nm to $400 \mathrm{~nm}$ ) being produced during this process must be understood. We can see that there are no radiations in the visible spectrum between $532 \mathrm{~nm}$ and $400 \mathrm{~nm}$ that generally correspond to harmful chemicals used in fireworks. Therefore, the Pravargya process that utilizes organic compounds that are normally vaporized below $1,000 \mathrm{~K}$ but produce temperature above $5,000 \mathrm{~K}$ and health beneficial radiation from IR to UV though for a short time.

John et al [16] concluded in their study that at around $70^{\circ} \mathrm{C}\left(158^{\circ} \mathrm{F}\right)$ viruses, specifically, SARS-CoV-2 (COVID-19), the new coronaviruses get destroyed. However, the time it takes to erase the virus completely would depend on how much virus is present on what type of surface. They did observe that at $75^{\circ} \mathrm{C}\left(167^{\circ} \mathrm{F}\right)$ temperature for a duration of 15 minutes 7 log reduction of the COVID19 virus. During Pravargya, we observed that Sun Surface like temperatures were produced rapidly that would help in destroying the viruses present in the ambient air.

\section{CONCLUSION}

Pravargya, great scientific process, generate enormous amount of temperatures closer to the temperatures that are present on the surface of Sun for a shorter period (in seconds). In the Pravargya Process, due to high temperatures the organic compounds in Cow Ghee, Cow Milk, and Goat Milk are likely to be excited to higher states and quickly drop to lower states by releasing Ultraviolet A (UVA) radiation with wavelength in the range of 320 to $400 \mathrm{~nm}$ (nano meters). These UVA rays destroy COVID-19 like viruses and other harmful bacteria covering larger areas surrounding the Pravargya location and hence provide immunity.

\section{ACKNOWLEDGMENT}

Authors would like to thank Organizers of Pragati Sudhama Resorts and Maharshi Vedic University for facilitating Vajepeya Soma Yaga. Dr. Raji Reddy and Mr. P. Chandra Sekhar Reddy from Pragati Sudhama helped us in accommodating our exploratory research. Authors would also like to thank the main priest - Veda Murthy Mangesh Bhavikar and other priests for their great contribution towards the Yaga. Mr. Chamundeshwar Duvalla helped in collecting Air Quality Index (AQI) data from the Yaga Location. Finally, we would like to thank all the members of Vedas World Inc for their continuous support and valuable suggestions.

\section{REFERENCES}

[1] Hui Zhou, YanQiu Long, AiHong Meng, Qing HaiLi, YanGuoZhang, Thermochimica Acta, Vol 566, 20th August 2013, Pages (36-43).

[2] Hui Zhou, Combustible Solid Waste Thermochemical Conversion, Springer Theses.

[3] Benjamin A. Hogue, Patrick W. Inglett, Nutrient release from combustion residues of two contrasting herbaceous vegetation types, Science of the Total Environment 431 (2012) 9-19.

[4] B. Mike WottonA, James S. Gould, W. Lachlan McCaw, N. Phillip Cheney, and Stephen W. Taylor, Flame temperature and residence time of fires in dry eucalypt forest, International Journal of Wildland Fire 2012, 21, 270-281.

[5] Divya Bangalore Raghavendra Prasad, Nagendra R Hongasandra, Amritanshu Ram, Investigation of random event generator changes in Agnistoma Somayaga rituals: An exploratory study, Journal of Health Research and Reviews 2016.

[6] Jan E.M. Houben, Indo-Iranian Journal 43: 1-25, 2000

[7] https://fdc.nal.usda.gov/fdc-app.html\#/food-details/1143824/nutrients

[8] https://fdc.nal.usda.gov/fdc-app.html\#/food-details/719112/nutrients

[9] https://fdc.nal.usda.gov/fdc-app.html\#/food-details/1028467/nutrients

[10] T.L. Dimitrova1, T.A. Eftimov, V.G. Kabadzhov, P.T. Panayotov, P.B. Boyanova, Scattering and fluorescence spectra of cow milk, Bulgarian Chemical Communications, Volume 46, Special issue B (pp. 39-43) 2014.

[11] Vanya Plachkova, Alexandra Zhelyazkova, Latchezar Avramov, Chavdar Zemyarski, Petar Petrov, Characterization of raw milk of ruminants by means of Fluorescence spectroscopy, International Journal of Scientific and Research Publications, Volume 6, Issue 2, February 2016.

[12] Jean Krutmann, Akimichi Morita, Mechanisms of Ultraviolet (UV) B and UVA Phototherapy, The Society for Investigative Dermatology, Vol. 4, No. 1 September 1999

[13] Edward C. De Fabo, Frances P. Noonan, Thomas Fears, Glenn Merlino, Ultraviolet B but not Ultraviolet A Radiation Initiates Melanoma, CANCER RESEARCH 64, 6372-6376, September 15, 2004. 


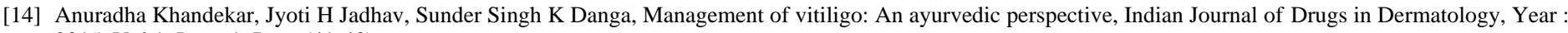
2015, Vol 1, Issue 1, Page (41-43).

[15] Naveed Ahmad, M Saleem, Studying heating effects on desi ghee obtained from buffalo milk using fluorescence spectroscopy, PLOS ONE |May 11, 2018.

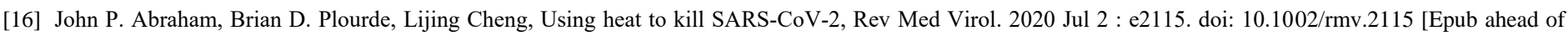
print] PMCID: PMC7361064

\section{AUTHORS}

First Author - Dr. Venkata R Chaganti, Ph.D. in Condensed Matter Physics, Vedas World Inc., GA, USA.

Second Author - Murali K Cheruvu, MS Data Science, Vedas World Inc., GA, USA.

Correspondence Author - Dr. Venkata Chaganti, vchaganti7@ gmail.com, +1 (229) 8545790. 